\title{
Investigation on the effect of mineral admixtures on mechanical property of self compacting concrete
}

\author{
Rayees Ali Khan
}

\begin{abstract}
Concrete is the mixture of cement sand and aggregate with a designed water-cement ratio. In RCC structural's concrete is vibrated heavily to flow through reinforcement bars which are less spaced. To solve this problem self compacting concrete is used. In this research ordinary Portland cement is partially replaced with silica fume and fly ash with different percentages $5 \%, 10 \%, 15 \%$ and $20 \%$ of fly ash and $1 \%, 2.5 \% .5 \%, 7.5 \%$ and $10 \%$ of silica fume for controlled mix design. In this research, the fresh and the hardened properties of concrete is determined it is shown that the fresh property of concrete is increased by increasing the percentage of silica fume and fly ash. It is observed that the mechanical properties of concrete are increased by the increase of silica fume and decreased the mechanical property by increasing the percentage of fly ash.
\end{abstract}

KEYWORDS: SELF COMPACTING CONCRETE, SILICA FUME, FLY ASH, FRESH PROPERTY, MECHANICAL PROPERTY.

\section{INTRODUCTION}

Self compacting concrete is one of the most used materials in civil engineering construction these days because of its good mechanical and fresh properties. There are many types of research done in this field with different names like self consolidation concrete, self-leveling concrete, highly-flow able concrete, super-workable concrete, and non-vibrating concrete. Self compacting concert flow easily at formwork even in the place of congested reinforcement under its own weight without using compacting machines. It is easily workable so reduce the extra labor charges. In this different chemical and mineral admixture are used to make it workable and increased the initial setting time for transportation. To reduce the cost the self compacting concert utilizes the waste and industrial by-products. The three main properties of self compacting concrete are its filling ability, passing ability, and segregation resistance. To measure these properties different tests are conducted. To test filling ability $T 50 \mathrm{~cm}$ slump test, $\mathrm{V}$ funnel is used, for passing ability $\mathrm{L}$ box, $\mathrm{U}$ box, $\mathrm{J}$ ring test and for segregation $\mathrm{V}$ funnel test at $\mathrm{T} 5$ minutes, etc are done. The main advantages of self compacting concrete are that the permeability of concrete is decreased, provide freedom for designing structural, time reduced, compacting machines eliminated hence reduce noise and coast for these things. But some limitations are the design mix needs more trials and more accuracy needed for measurement and monitoring of material. In the present study, the fresh and mechanical properties of

\footnotetext{
* Correspondence Author

${ }^{l}$ Rayees ali khan: Department of Civil Engineering, Sharda University, Greater Noida, Uttar Pradesh, India.
}

concrete should be determined by the use of silica fume and fly-ash with different percentages.

\section{SCOPE:}

The aim of the research is as we know the rate of growing industries is very fast so, we need some quick and accurate methods of construction and also utilize the waste materials by-products self compacting concrete can do this.

\section{METHODOLOGY}

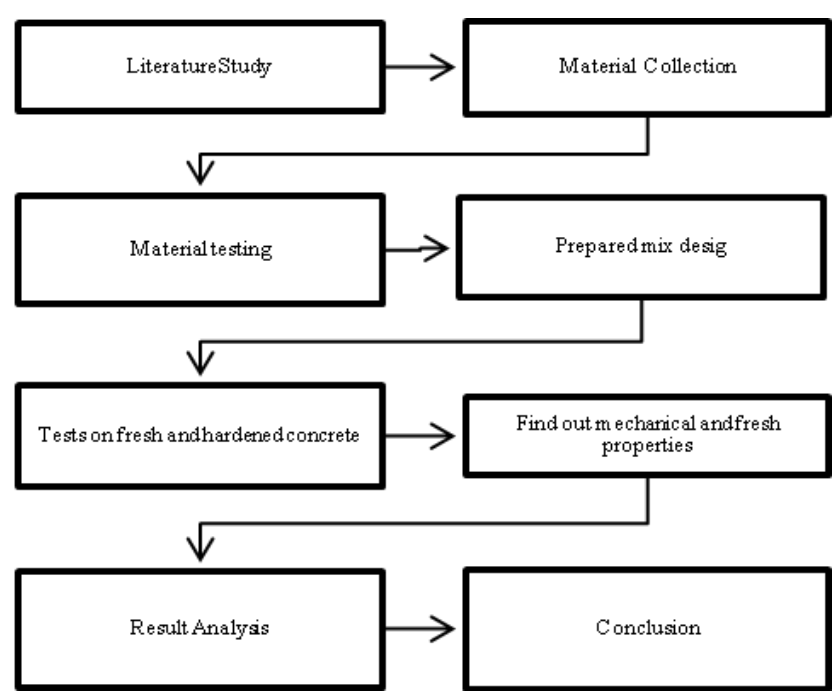

\section{MATERIAL TESTING:}

a) Cement:

As we know that cement is a binding material in mortar and concrete and composed of raw materials. In this research ordinary Portland cement of grade 43 used with a specific gravity of 3.1 and finesse $2 \%$ retained upon the 90 microns IS sieve.

b) Fly ash:

It is a coal combusted product compost of fine particles by the use of fly ash workability significantly improved. In physical property, the specific gravity of fly ash is 2.25 . 
Investigation on the effect of mineral admixtures on mechanical property of self compacting concrete

Table I: Chemical properties of fly ash.

\begin{tabular}{|l|l|l|}
\hline S.NO & Chemical component & $\begin{array}{l}\text { Percentage of chemical } \\
\text { component }\end{array}$ \\
\hline $\mathbf{1}$ & $\mathrm{SiO}_{2}$ & 50.1 \\
\hline $\mathbf{2}$ & $\mathrm{Fe}_{2} \mathrm{O}_{3}$ & 14.12 \\
\hline $\mathbf{3}$ & $\mathrm{Al}_{2} \mathrm{O}_{3}$ & 22.4 \\
\hline $\mathbf{4}$ & $\mathrm{CaO}$ & 3.6 \\
\hline $\mathbf{5}$ & $\mathrm{MgO}$ & 1.22 \\
\hline $\mathbf{6}$ & $\mathrm{K}_{2} \mathrm{O}$ & 0.59 \\
\hline $\mathbf{7}$ & $\mathrm{Na}_{2} \mathrm{O}$ & 0.42 \\
\hline $\mathbf{8}$ & $\mathrm{SO}_{3}$ & 0.98 \\
\hline
\end{tabular}

\section{c) Silica fume:}

Silica fume is a very fine amorphous silica product also known as micro silica. It is a by-product of silica-alloys. The specific gravity of silica fume 2.21 .silica fume is added to ordinary Portland cement to increase the mechanical property of cement.

Table II: Chemical properties of silica fume.

\begin{tabular}{|l|l|l|}
\hline S.NO & Chemical component & $\begin{array}{l}\text { Percentage of chemical } \\
\text { component }\end{array}$ \\
\hline $\mathbf{1}$ & $\mathrm{SiO}_{2}$ & 86 \\
\hline $\mathbf{2}$ & $\mathrm{Fe}_{2} \mathrm{O}_{3}$ & 0.5 \\
\hline $\mathbf{3}$ & $\mathrm{Al}_{2} \mathrm{O}_{3}$ & 0.2 \\
\hline $\mathbf{4}$ & $\mathrm{CaO}$ & 0.21 \\
\hline $\mathbf{5}$ & $\mathrm{MgO}$ & 0.5 \\
\hline $\mathbf{6}$ & $\mathrm{K}_{2} \mathrm{O}$ & 0.5 \\
\hline $\mathbf{7}$ & $\mathrm{Na}_{2} \mathrm{O}$ & 0.2 \\
\hline $\mathbf{8}$ & $\mathrm{SO}_{3}$ & 0.14 \\
\hline $\mathbf{9}$ & $\mathrm{C}_{1}$ & 0.01 \\
\hline $\mathbf{1 0}$ & $\mathrm{H}_{2} \mathrm{O}$ & 0.5 \\
\hline
\end{tabular}

d) Fine aggregate:

Aggregate which passed through $4.75 \mathrm{~mm}$ IS sieve. In this research local available fine aggregate is used. Fineness modulus 2.68 and specific gravity 2.6 .

\section{e) Coarse aggregate:}

Aggregate which retains upon the IS $4.75 \mathrm{~mm}$ sieve. In this research maximum of $20 \mathrm{~mm}$ single-sized aggregate used. The specific gravity of course aggregate is 2.7 , water absorption 0.65 and Bulk density $\mathrm{kg} / \mathrm{m}^{3}$ equal to 1630.1

\section{f) Auramix 350:}

Auramix 350 is a high-performance superplasticizer suitable for low and high-grade concrete and intended for applications where high water reduction and long workability retentions are required.ph value is 6 and specific gravity 1.1 appx.

\section{g) Water:}

The water used in this research is drinkable water of $\mathrm{Ph}$ 6.7-8.4

\section{MIX DESIGN:}

The mix design proportion is designed as per the IS IS10262-2009. Use of Superplasticizer Auramix 350 (0.9\%) by weight of cement to increase the workability.

\begin{tabular}{|l|l|l|l|}
\hline Water & Cement & $\begin{array}{c}\text { Fine } \\
\text { aggregate } \\
\left(\mathbf{K g} / \mathbf{m}^{\mathbf{3}}\right)\end{array}$ & $\begin{array}{c}\text { Coarse } \\
\mathbf{( K g / \mathbf { m } ^ { 3 }} \\
\mathbf{a g g r e g a t e} \\
\left(\mathbf{K g} / \mathbf{m}^{\mathbf{3}}\right)\end{array}$ \\
\hline 202.77 & 550 & 775.312 & 788.12 \\
\hline 0.36 & 1 & 1.40 & 1.43 \\
\hline
\end{tabular}

From the mix proportion, the weight of fly ash and silica fume required is calculated.

Table III: In different percentage weight of cement and silica fume required.

\begin{tabular}{|l|l|l|l|}
\hline $\begin{array}{l}\text { Sample } \\
\text { name }\end{array}$ & $\begin{array}{l}\text { Replacement } \\
\text { percentage of } \\
\text { cement by fly ash }\end{array}$ & $\begin{array}{l}\text { Silica } \\
\text { fume } \\
\left(\mathrm{Kg} / \mathrm{m}^{3}\right)\end{array}$ & $\begin{array}{l}\text { Cement } \\
\left(\mathrm{Kg} / \mathrm{m}^{3}\right)\end{array}$ \\
\hline SF1 & $1 \%$ & 5.5 & 544.5 \\
\hline SF2 & $2.5 \%$ & 13.75 & 536.25 \\
\hline SF3 & $5 \%$ & 27.5 & 522.25 \\
\hline SF4 & $7.5 \%$ & 41.25 & 508.75 \\
\hline SF5 & $10 \%$ & 55 & 495 \\
\hline
\end{tabular}

Table IV: In different percentage weight of cement and fly ash required.

\begin{tabular}{|l|l|l|l|}
\hline $\begin{array}{c}\text { Sample } \\
\text { name }\end{array}$ & $\begin{array}{l}\text { Replacement } \\
\text { percentage of } \\
\text { cement by fly } \\
\text { ash }\end{array}$ & $\begin{array}{l}\text { Fly } \\
\text { ash }\left(\mathrm{Kg} / \mathrm{m}^{3}\right)\end{array}$ & $\begin{array}{l}\text { Cement } \\
\left(\mathrm{Kg} / \mathrm{m}^{3}\right)\end{array}$ \\
\hline FA1 & $5 \%$ & 27.5 & 522.5 \\
\hline FA2 & $10 \%$ & 55 & 495 \\
\hline FA3 & $15 \%$ & 82.5 & 467.5 \\
\hline FA4 & $20 \%$ & 110 & 440 \\
\hline
\end{tabular}

\section{RESULTS AND DISCUSSION:}

\section{A. Fresh properties of concrete}

a) Workability: easy by which concrete can be a mixture, transported and compacted without bleeding and segregation. It is a physical parameter that affects the strength and durability of concrete. 
Table V: Workability of Concrete.

\begin{tabular}{|l|l|l|}
\hline S.NO & SPECIMEN & $\begin{array}{l}\text { WORKABILITY } \\
(\mathrm{mm})\end{array}$ \\
\hline $\mathbf{1}$ & $\begin{array}{l}\text { Conventional } \\
\text { With Auramix 350 }(\mathbf{0 . 9 \%})\end{array}$ & $\mathbf{1 1 0}$ \\
\hline $\mathbf{2}$ & SF1 & $\mathbf{1 1 5}$ \\
\hline $\mathbf{3}$ & SF2 & $\mathbf{1 2 3}$ \\
\hline $\mathbf{4}$ & SF3 & $\mathbf{1 2 8}$ \\
\hline $\mathbf{5}$ & SF4 & $\mathbf{1 3 4}$ \\
\hline $\mathbf{6}$ & SF5 & $\mathbf{1 3 9}$ \\
\hline $\mathbf{7}$ & FA1 & $\mathbf{1 4 5}$ \\
\hline $\mathbf{8}$ & FA2 & $\mathbf{1 3 0}$ \\
\hline $\mathbf{9}$ & FA3 & $\mathbf{1 2 2}$ \\
\hline $\mathbf{1 0}$ & FA4 & $\mathbf{1 1 9}$ \\
\hline
\end{tabular}

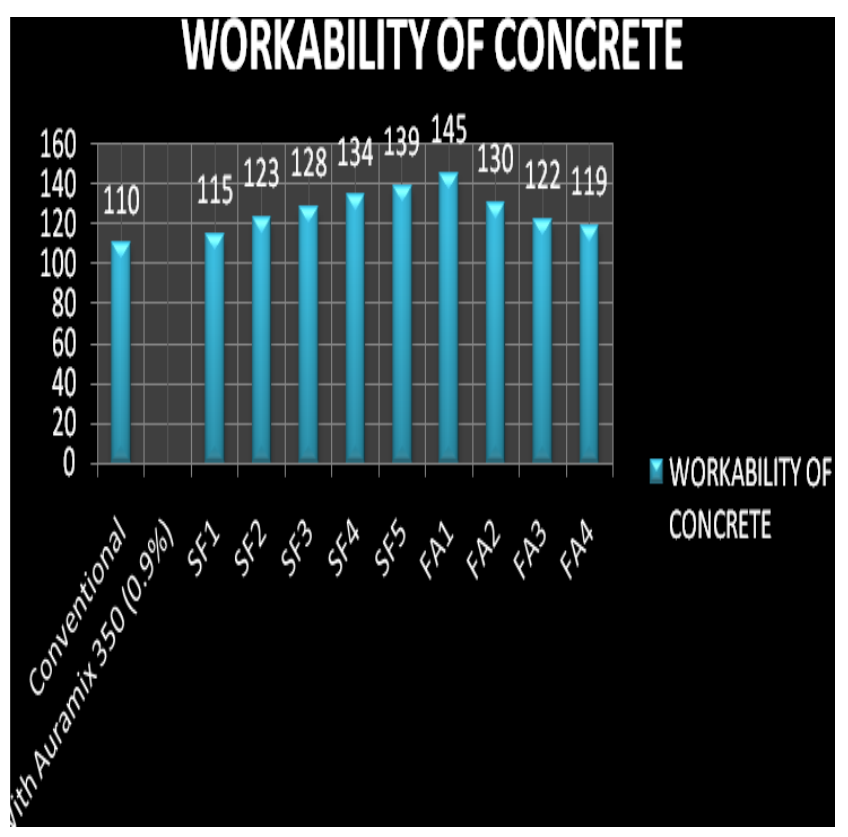

Figure 1: Workability Of Concrete.

\section{B. Hardened Properties:}

a) Compressive Strength: It is the ability of a material to resist compressive forces which tends to compress it. Cubes of dimension $150 \times 150 \times 150 \mathrm{~mm}$ are cast both for conventional as well as for self compacting concrete. Concrete is filled in three layers and fully compacted allow to sit for 24 hours and then demoulding and put under the curing process after 28 days cubes are taken out and tested under the compressive testing machine.

Table VI: Compressive strength of concrete by using silica fume and fly ash.

\begin{tabular}{|l|l|l|}
\hline S.NO & SPECIMEN & $\begin{array}{l}\text { COMPRESSIVE STRENGTH } \\
(\mathrm{MPa})\end{array}$ \\
\hline 1 & $\begin{array}{l}\text { Conventional with } \\
0.9 \% \text { of Auramix }\end{array}$ & 50.48 \\
\hline
\end{tabular}

\begin{tabular}{|l|l|l|}
\hline & 350 & \\
\hline 2 & SF1 & 52.8 \\
\hline 3 & SF2 & 54.1 \\
\hline 4 & SF3 & 55.2 \\
\hline 5 & SF4 & 57.4 \\
\hline 6 & SF5 & 58.1 \\
\hline 7 & FA1 & 48 \\
\hline 8 & FA2 & 48.9 \\
\hline 9 & FA3 & 46.7 \\
\hline 10 & FA4 & 44.8 \\
\hline
\end{tabular}

\section{COMPRESSIVESTRENGTH(MPa)}

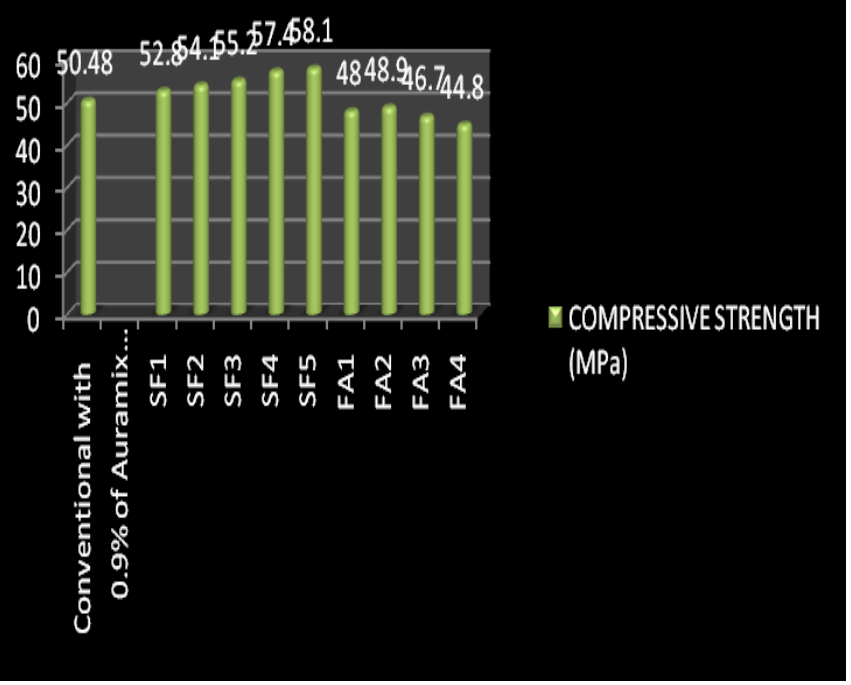

Figure 2: Compressive strength of concrete by using silica fume and fly ash.

b) Split Tensile Strength: In this test cylinder of dimension $150 \mathrm{~mm}$ dia. $300 \mathrm{~mm}$ height is used to determine the split tensile strength this method is an indirect method to determine the tensile strength of concrete. In this test, cylinder put longitudinally and a compressive force is applied, cylinder split into two parts the reading is noted own and find the split tensile strength of concrete by using formula $\mathrm{T}=2 \mathrm{P} / \pi \mathrm{DL}$

Table VII: Split tensile strength of concrete by using silica fume and fly ash.

\begin{tabular}{|l|l|l|}
\hline S.NO & SPECIMEN & $\begin{array}{l}\text { Split tensile STRENGTH } \\
(\mathrm{MPa})\end{array}$ \\
\hline 1 & $\begin{array}{l}\text { Conventional with } \\
0.9 \% \text { of Auramix } 350\end{array}$ & 4.21 \\
\hline 2 & SF1 & 4.25 \\
\hline 3 & SF2 & 4.38 \\
\hline 4 & SF3 & 4.51 \\
\hline 5 & SF4 & 4.8 \\
\hline 6 & SF5 & 4.97 \\
\hline 7 & FA1 & 3.91 \\
\hline 8 & FA2 & 3.98 \\
\hline 9 & FA3 & 3.67 \\
\hline
\end{tabular}




\begin{tabular}{|l|l|l|}
\hline 10 & FA4 & 3.46 \\
\hline
\end{tabular}

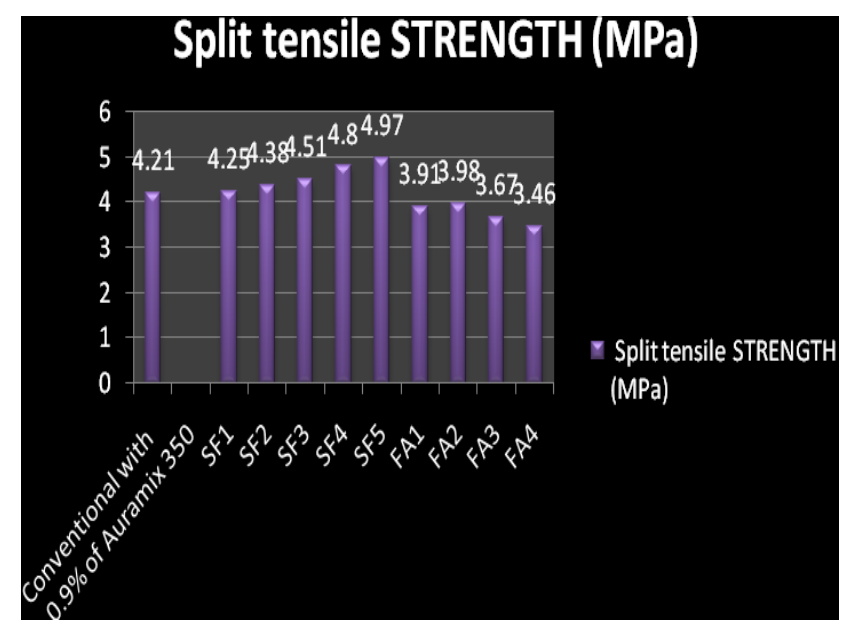

Figure 3: Split tensile strength of concrete by using silica fume and fly ash.

\section{CONCLUSION:}

The outcome from the above research is:

- Form the above result is shown that the compression strength decreased with an increase in the percentage of fly ash while as it increased with increasing the percentage of silica fume.

- As considering a fresh property the workability of concrete increased with the increased percentage of silica fume but in the cause of fly ash cement replaced upto5\% it increased if we increased the replacement percentage cement with fly ash it gets decreased.

- While in the cause of tensile strength when cement is replaced with fly ash the tensile strength decreased but in the cause when we replaced cement with silica fume tensile strength increased.

It is shown that the use of silica fume increased the fresh and hardens property of concrete and the use of its environmental hazards gets reduced. Among both of them, silica fume and fly ash the silica fume gives more positive results.

\section{REFERENCES:}

[1] F. Aslani, G. Ma, D. Law, Y. Wan, and G. Muslin "Development of high-performance self-compacting concrete using waste recycled concrete aggregates and rubber granules," J. Clean. Prod., 2018.

[2] R. K. Sandhu and R. Siddique, "Influence of rice husk ash ( RHA ) on the properties of self-compacting concrete: A review," Constr. Build. Mater., vol. 153, pp. 751-764, 2017.

[3] S. Dadsetan and J. Bai, "Mechanical and microstructural properties of self-compacting concrete blended with metakaolin, ground granulated blast-furnace slag and fly ash," Constr. Build. Mater., vol. 146, pp. 658-667, 2017.

[4] B. Vakhshouri, "ANFIS Application to Predict the Compressive Strength of Lightweight Self-Compacting Concrete," no. December, pp. 28-35, 2016.

[5] R. Bani, A. Joshaghani, and R. D. Hooton, “Workability retention and compressive strength of self-compacting concrete incorporating pumice powder and silica fume," Constr. Build. Mater., vol. 134, pp. 116-122, 2017.

[6] S. Manzi, C. Mazzotti, and M. C. Bignozzi, "Self-compacting concrete with recycled concrete aggregate : Study of the long-term properties," Constr. Build. Mater., vol. 157, no. 2017, pp. 582-590, 2020 .

[7] M. Omrane, S. Kenai, E. Kadri, and A. Abdelkarim, "Performance and Durability of Self Compacting Concrete using Recycled Concrete Aggregates and Natural Pozzolan," J. Clean. Prod., 2017.

[8] D. E. Eh, "INVESTIGATION ON THE EFFECTS OF BLENDED ADMIXTURES ON WORKABILITY OF SELF COMPACTING CONCRETE," (IEEE), vol. 6, pp. 42-47, 2017.

[9] S. M. Hama and N. N. Hilal, "Fresh properties of self-compacting concrete with plastic waste as partial replacement of sand," Int. J. Sustain. Built Environ., vol. 6, no. 2, pp. 299-308, 2017.

[10] H. Y. Leung, J. Kim, A. Nadeem, J. Jaganathan, and M. P. Anwar, "Sorptivity of self-compacting concrete containing fly ash and silica fume," Constr. Build. Mater., vol. 113, pp. 369-375, 2016.

[11] Y. Ouldkhaoua, B. Benabed, R. Abousnina, E. Kadri, and J. Khatib, "Effect of using metakaolin as supplementary cementitious material and recycled CRT funnel glass as fine aggregate on the durability of green self-compacting concrete," Constr. Build. Mater., vol. 235, p. 117802, 2020.

[12] A. Dinesh, "Experimental study on self compacting concrete," no. March 2017.

[13] E. M. Raisi, J. V. Amiri, and M. R. Davoodi, "Mechanical performance of self-compacting concrete incorporating rice husk ash," Constr. Build. Mater., vol. 177, pp. 148-157, 2018.

[14] A. S. Gill and R. Siddique, "Durability properties of self-compacting concrete incorporating metakaolin and rice husk ash," Constr. Build. Mater., vol. 176, pp. 323-332, 2018.

[15] K. K. M. E, S. P. S. P. D, and B. S. P. D, "Durability of self-compacting concrete made with Recycled Concrete Aggregates and mineral admixtures," Constr. Build. Mater., vol. 128, pp. 67-76, 2016.

[16] D. M. Sadek, M. M. El-attar, H. A. Ali, and M. Student, "Reusing of Marble and Granite Powders in Self-Compacting Concrete for Sustainable Development," J. Clean. Prod., 2016. 